\title{
Da Criação Literária Universitária como Contra-hegemonia ao Estado Novo: O Caso da Via Latina (1958- 1962)
}

Resumo:

Este artigo tem como propósito avaliar a criação e difusão literária dos estudantes da Associação Académica de Coimbra (AAC) durante o período compreendido entre 1958 e 1962. A cronologia eleita é justificada pela candidatura de Humberto Delgado às eleições presidenciais de 1958, que traz consigo a politização de diversos setores da sociedade, e pela primeira crise académica, de 1962. Na revista da AAC, Via Latina, foram publicados, durante o período mencionado, bastantes contos e ensaios literários de estudantes universitários. Esta produção denota uma clara influência das correntes artísticas que então dominavam o panorama cultural português. Inspirados pelo neorrealismo e pelo existencialismo, bem como por ensejos políticos democratizantes, estes autores levaram a cabo uma transformação do panorama cultural universitário e coimbrão. Para uma análise mais rica, a Via Latina é comparada com outras revistas académicas da época. Este artigo recorreu a entrevistas feitas a membros da revista.

Palavras-chave:

Literatura, Estado Novo, Universidade, Cultura, Neorrealismo

Abstract:

This article aims to evaluate the creation and literary dissemination of students from the Academic Association of Coimbra (AAC) during the period between 1958 and 1962. The chronological limits are justified by Humberto Delgado's candidacy to the 1958 presidential elections, which brings with it the politicization of different sectors of society, and the first academic crisis, in 1962. During the period mentioned in the AAC magazine, Via Latina, many short stories and literary essays by university students were published. This production denotes a clear influence of the artistic currents that dominated the Portuguese cultural panorama at the time. Inspired by neo-realism and existentialism, as well as by democratizing political opportunities, these authors carried out a transformation of the university and Coimbra's cultural panorama. For a richer analysis, Via Latina is compared with other academic journals of the time. This article has used interviews with members of the magazine. 
Keywords:

Literature, Estado Novo, University, Culture, Neo-realism

Durante o final da década de 1950, a ditadura do Estado Novo entrou num período de considerável crispação social e política. A crescente oposição à sua tutela sobre a sociedade portuguesa foi marcada por uma série de eventos tais como a candidatura de Humberto Delgado às eleições presidenciais de 1958, o assalto ao paquete Santa Maria por Henrique Galvão e a fortificação do movimento estudantil (Rosas 1994: 579). Este último foi potenciado pela contestação das associações de estudantes ao decreto governamental 40.900, de 1957, que procurava submeter estas organizações ao controlo direto pelo governo (Garrido 1996). O combate pela autonomia académica e pelos ideais democráticos conduziu a uma paulatina radicalização política dos estudantes, que viria a culminar na primeira crise académica, em abril de 1962. Para além das reivindicações autonomistas, o movimento estudantil recorreu a outras formas de luta contra a hegemonia cultural e política da ditadura salazarista, dentro das quais se destaca a produção literária.

Na cidade de Coimbra, desde o final da década de 1950, os estudantes levaram a cabo, na revista da Associação Académica de Coimbra (AAC) Via Latina, a criação de um corpus literário de pendor marcadamente reivindicativo. Esta tendência foi enfatizada pela eleição da lista de esquerda, de Carlos Candal, para a presidência da AAC, em 1960 (Garrido 1996: 20-30). Após a tomada de posse da lista de Candal, a produção escrita dos estudantes publicada na Via Latina passou a absorver bem como a plasmar influências das correntes literárias criadas pelos artistas portugueses que militavam nas fileiras das oposições, artísticas e políticas, à ditadura.

Até aos princípios da década de 1960, os movimentos artísticos e literários que dominavam a cultura portuguesa eram praticamente os mesmos que se haviam sedimentado durante as décadas anteriores. De um lado estava a literatura oficial do regime que procurou incorporar sob a sua égide escritores clássicos portugueses ao enquadrá-los na doutrina corporativista salazarista, bem como outros autores "menores" contemporâneos (Torgal 1999: 408-409). No polo oposto encontram-se correntes como o neorrealismo, o presencismo e o surrealismo. Bem como o existencialismo, que marcou a sua entrada nos circuitos intelectuais portugueses no final da década de 1940 (Saraiva/Lopes 2000: 1048-1058), só se manifestando, contudo, no final do decénio seguinte nas revistas culturais estudantis. Como irá ser apresentado, a Via Latina mostrou um maior compromisso para com a estética neorrealista do que outras publicações estudantis da época. Para levar a cabo uma caracterização mais detalhada da Via Latina serão efetuadas comparações com outras revistas universitárias, como a Quadrante, dos estudantes da Faculdade de Direito de Lisboa, e a Encontro, dos estudantes católicos de Lisboa.

Para além dos autores e dos diversos movimentos literários em Portugal durante a época destacam-se duas revistas de enorme peso na cultura oposicionista: Seara Nova ${ }^{1}$ e Vértice, ${ }^{2}$ 
publicações que serviram como rampa de lançamento para a difusão de vários autores, ensaístas e teóricos. De acordo com Rui Namorado e António Avelãs Nunes, ${ }^{3}$ a Vértice "representa a publicação que mais influência teve sobre os estudantes de Coimbra, "mais do que a Seara Nova, apesar da admiração nutrida por um pensador progressista como António Sérgio" (Namorado 2015; Nunes 2015). Até que ponto se propagou o influxo da Vértice pelos estudantes de Coimbra é impossível precisar com objetividade. Sobressaem vários indícios na Via Latina que revelam uma certa homogeneidade neorrealista no meio estudantil coimbrão. Esta articulação pode ser justificada pelo facto de as revistas Vértice e Novo Cancioneiro terem constituído as únicas publicações da cultura oposicionista existentes na cidade.

Antes da esquematização das tendências literárias da Via Latina, convém explicitar que alguns autores inseridos no quadro contra-cultural português, principalmente os de inspiração marxista, "sentiam-se menos como artistas do que como militantes de uma ideia" (Torgal 1999: 406), sendo a intervenção política o principal motivo da sua produção literária. Esta literatura politizada começou a dar sinais de vida nas páginas da Via Latina após a aprovação do decreto 40.900. Se durante as décadas de 1940 e 1950 foi publicado um escasso rol de contos e poemas enquadráveis na estética neorrealista, foi com o agudizar das relações entre a academia de Coimbra e o governo que estes proliferaram, bem como outros contos distintos do movimento que possuíam igualmente uma forte componente de crítica social e política. Veja-se um conto publicado durante uma direção da AAC afeta ao regime salazarista de seu nome "Recordações de um escravo romano", que apresenta um escravo copista. Baseado na exposição da personagem aos manuscritos, o autor empreende uma reflexão onde discorre sobre a importância da memória histórica, as implicações da mistificação de acontecimentos por parte de entidades governamentais e a deificação de figuras históricas:

Entretanto vamos aguardando a certeza de que tais figuras históricas se reabilitarão em nós e por nós, dentro do tal plano de repetição de factos do passado. Condenaremos as que não se integrarem no conceito exigido da inteira realização humana: exaltaremos as que se elevarem a um plano máximo, figuras típicas de todas as civilizações, símbolos recorrentes que os espíritos fracos e sem imaginação tendem a idolatrar, caindo por vezes (isto é, em determinadas épocas históricas), na feitura de novos mitos e novas religiões. Deixemos os historiadores continuar na sua labuta arqueológica, desenterrando falsidades nos arquivos imperiais, entorpecendo a imaginação com uma arreigada submissão à ordem histórica tradicional[.] (Mota, "Recordações": 5-6)

O desdém pela cultura oficial do Estado Novo é patente nas reflexões apresentadas. Ao nomear as "figuras típicas de todas as civilizações" como "símbolos recorrentes que os espíritos fracos tendem a idolatrar", o conto procura evidenciar as implicações que se camuflam no endeusamento das figuras históricas por parte das culturas oficiais dos estados. Neste sentido é possível estabelecer paralelo entre esta problematização e o conceito de hegemonia de Antonio Gramsci. De acordo com Gramsci, a ideologia do "grupo social fundamental" (burguesia) afir- 
ma-se sobre a ideologia dos "grupos subordinados" (proletariado), resultando numa combinação de coerção e consentimento. Será, portanto, necessária a afirmação de uma cultura revolucionária para quebrar com a hegemonia do "grupo social fundamental" (Gramsci 1974: 330).

Contudo, "Recordações de um escravo romano" não se insere dentro de nenhum género literário específico e apresenta características próximas de um texto de carácter ensaístico. Os estudantes que escreveram contos para a Via Latina inspiraram-se fundamentalmente no neorrealismo.

\section{O neorrealismo na Via Latina}

A corrente literária que mais se destacou na Via Latina é, durante o período 1958-1962, a neorrealista. Atente-se à publicação de contos e poemas de autores que se enquadraram no movimento, como Fernando Namora, Manuel da Fonseca ou Urbano Tavares Rodrigues. A forte influência desta corrente deve-se em boa medida à revista Vértice, que, tendo o seu centro nevrálgico em Coimbra (apesar de contar com colaboradores do exterior), favoreceu a proeminência desta tendência no meio estudantil da cidade (Namorado 2015). De facto, em nenhuma outra publicação universitária da época se denota um compromisso tão grande para com o neorrealismo. Este movimento, que paulatinamente se foi revelando no meio intelectual da cidade durante os primeiros anos da década de 1940, só ocasionalmente foi mencionado nas páginas da revista durante as décadas de 1940 e 1950.

Contudo, nos últimos dois anos da década de 1950, foram publicados ensaios e contos de evidente cunho neorrealista, redefinindo assim as prioridades literárias da publicação. Os heróis literários da revista, desde os seus primórdios, foram os membros da geração de 70. Nos anos finais de 1950 a atenção dada a estes autores perpetua-se; todavia, as produções literárias dos estudantes contemporâneos são levadas a primeiro plano.

Os contos neorrealistas escritos pelos estudantes possuíam atributos que os aproximavam das obras inseridas na primeira fase deste movimento (Torres 1977: 10-19). O ambiente e as personagens são quase exclusivamente rurais, e a linguagem empregue é limpa e direta. Tomemos como exemplo dois contos de Manuel Mansilha. Em "Vindimas" o autor estabelece uma dicotomia entre labor árduo e um certo hedonismo, encetando uma comparação que frisa as suas inspirações:

E os bois que, pacatamente, e a passo de boi, arrastam a dorna enquanto o carro assobia e as videiras cospem lágrimas de desgosto por lhes roubarem os cachos - filhos, como os filhos da gente, levaram um ano a criar e agora vêem partir para serem espezinhados num lagar. Ainda se a videira soubesse que aquelas uvas vão ter um fim digno. Vão ser vinho que pode muito bem, subir ao Altar! ("Vindimas": 8)

O diálogo empregue neste conto procura também aproximar-se dos jargões característicos da linguagem rural: 
- ó tonho, despeja lá esta cesta.

- Ai filho da mãe... avia-te que já tenho o regaço a abarrotar.

- ó tiazinha, isto não é uma sementeira.

- Olha-me para esses bagos que estão aí no chão!

- Eh rapariga, parece que andas à caínça. Num vês o respigo que deixavas neste barbo, Quase uma videira. Raios te partam! Vê se te faz minga abrir-te os olhos. [sic] ("Vindimas": 13)

O recurso a expressões populares, subordinado à tentativa de procurar reproduzir a linguagem popular de modo fiel, foi uma das preocupações dos autores neorrealistas (Ramond 2008). Vejam-se os mais representativos romances do género, como Gaibéus (1939) e Esteiros (1941). Manuel Mansilha revela por fim que a escrita deste conto foi inspirada por acontecimentos que ele próprio presenciou, tornando este pequeno texto ainda mais próximo das obras neorrealistas da primeira fase, que, de acordo com os seus autores, foram baseadas em experiências testemunhadas pelos próprios: ${ }^{4}$

Tudo recordo e pareço compreender melhor deste miradouro distante. Daqui parece maior o homem rude que é um gigante no seu trabalho suado. Torna-se escabroso o caminho das rogas. Chegam a até mim os acordes da concertina, ferrinhos e bombo, como se fossem trazidos preguiçosamente, docemente, por um barco rabelo. Por isso eu recordo os barcos rabelos. Por isso eu recordo os Muros e Mondego. ("Vindimas": 13)

Para além deste conto, o autor publicou "Homens da Serra", que, seguindo o mesmo modelo de "Vindimas", descreve o modus vivendi de uma família de pastores.

Por sua vez, "A Montanha", de Torres Neiva, relata a história de uma família de pastores que habita a região agreste dos montes beirões. Dando principal enfoque ao filho do pastor, um jovem que devido às exigências impostas se vê obrigado a comportar-se como um adulto, Neiva traça o perfil psicológico da personagem principal recorrendo ao binómio adulto/criança em contornos reminiscentes aos de Esteiros (1941) de Soeiro Pereira Gomes:

Quim, [sic] começou a acompanhar o pai nessa ronda dos pinhais. O Quim. Catorze. Quinze anos quando muito. Uma varita adolescente de marmeleiro na mão e o casaquito aos ombros como os homens à vinda do trabalho. E aqueles olhitos a entrarem por meio dos pinheiros, com duas rugas em arco na testa. O pai em letra minúscula. ("A Montanha": 12)

O grosso dos contos neorrealistas insere-se dentro da categoria da primeira fase do movimento, ou seja, partindo de um cenário rural, com recurso a uma linguagem vernacular, procura recriar ou retratar a dureza da vida campestre, contrapondo-a com rasgos poéticos que constroem um padrão consideravelmente mistificado do trabalhador rural.

Já em "Uma história para os pobres" Teolinda Gersão criou um conto que será mais facilmente enquadrável na segunda fase do movimento. Não só por eleger a cidade como o palco da 
ação, mas principalmente por recorrer a uma ironia excessiva para os padrões do neorrealismo original. A autora apresenta o conto, fazendo justiça ao título, como uma história para pobres e que "por isso nem sequer é história". Apenas "que se abre - lá em cima, nas águas-furtadas e se torna a fechar sobre o escuro. Começa aí. Mas acaba aí. Não é história" ("Pobres": 3). Após a introdução é identificado um dos protagonistas, Pedro, que caminha à chuva pelas ruelas de um bairro de lata até entrar no seu casebre. Ao entrar, Teresa, a sua mulher, atira-lhe uma toalha feita de remendos para que se seque. Quando descalça as meias, Teresa constata que estas estão completamente rotas. A esposa não consegue manter-se calma, devido à chuvada intensa que abala o casebre. "Agora ela está sentada num joelho bicudo, a chuva bate no alboio [(alpendre)] como se pedisse para entrar." O vento entra pelas frinchas da casa e Pedro imita-o assobiando, "num sopro fininho". Teresa diz que vai fazer um café:

A Teresa enche a fogueira a cafeteira e põe-na no fogão do petróleo. Álcool... álcool. Aqui está o frasco na prateleira dos livros. Oh, vazio. Mas há perfume. "Channel". Um bocadinho chega, só para acender o lume. E depois, até o chá fica perfumado quando daí a pouco eles o beberem, pelo mesmo copo de plástico. ("Pobres": 3)

Enquanto prepara o café a mulher relata-lhe o seu final de tarde: "Eu estive a ver chover, sentada num alboio. Macia, macia. Lá em baixo na rua. Passavam guarda-chuvas. Havia-os de todas as cores, eram pequenos cogumelos errantes. Os candeeiros eram estrelas. E os faróis dos carros, pirilampos. A rua era um jardim" ("Pobres": 3).

Quando Teresa metaforiza o ambiente urbano através de elementos campestres, pode estar a indicar que o casal se deslocou da aldeia para a cidade. Pedro recorda-se subitamente da comida que trouxera para o jantar: "Que estúpido que eu sou. Então não me esqueci dos rissóis? Vinham tão quentinhos da loja. Do bolso da gabardine saiu uma bola amassada e húmida. Não se distingue bem onde acaba o primeiro e começa o segundo." Teolinda Gersão finaliza o conto com o seguinte remate:

O barulho da rua morre lá em baixo. Os ratos agitam-se no forro. E agora eu não sei o que dizer mais. A história, se é que alguma vez começou, acaba aqui. A porta está fechada. A luz apagou-se e há um retângulo de noite colado no alboio. A música da chuva pinga no telhado. E é tudo. É uma história para os pobres. Eu logo disse que nem sequer era uma história. ("Pobres": 3)

O local da ação do conto nunca é especificado, o leitor sabe apenas que o cenário é um bairro de lata. Certamente que se passará na periferia de um grande centro urbano. No final da década de 1950 e com o aumento da população, dá-se um surto migratório no qual milhares de portugueses em busca de trabalho e melhores condições de vida se dirigem para os perímetros urbanos. Nos primeiros anos da década seguinte, outros milhares de portugueses emigraram para França. Muitos acabaram a morar nos bairros de lata da periferia de Paris, os chamados bidonvilles, onde se sujeitaram a condições de vida bastante precárias (Rosas 1994: 450-460). 
"Uma história para pobres" tecnicamente não se pode passar nos bidonvilles, porque o surto migratório que os origina só ocorreu nos primeiros anos da década de 1960. Não deixando de se adequar à situação de muitos emigrantes portugueses. Todavia, para uma interpretação mais exata do conto, este deve apenas ser visto à luz da realidade portuguesa do final da década de 1950, quando o êxodo rural provocado pelo desemprego, tal como pela nova vaga de industrialização dos centros urbanos e das suas áreas circundantes, compeliu muitas famílias a deslocarem-se para as zonas periféricas das cidades.

O peso da revista Vértice foi de facto enorme na cultura universitária de Coimbra. Em nenhuma outra revista universitária nacional se registam as mesmas características que na Via Latina. Os redatores do jornal académico inseriram artigos integralmente retirados da Vértice, acompanhados de uma nota indicadora da origem dos mesmos, de ensaios críticos sobre a obra de Fernando Namora a poemas de Manuel da Fonseca acompanhados de ilustrações de Manuel Ribeiro Paiva. O franqueado contraste entre a Via Latina e as restantes revistas académicas nacionais sintomatiza a importância que cada uma atribuiu a determinadas correntes artísticas, e em nenhuma outra publicação estudantil da época se dedica tanto espaço ao neorrealismo.

A revista Quadrante, da Faculdade de Direito da Universidade de Lisboa, publicou alguns poemas neorrealistas, mas revela maior fascínio pelas vanguardas de carácter experimental ou "fantástico". Vejamos os vários poemas de Cesariny, O’Neill, ensaios dedicados a Kafka, acompanhados de desenhos de plástica surrealista, publicados no primeiro número, ou um ensaio, publicado no número seguinte, sobre a importância da poesia, que inclui citações de Stéphane Mallarmé e do Conde de Lautréamont, dois dos mais famosos poetas malditos que se encontram consignados no panteão dos surrealistas. O movimento surrealista, que se desenvolveu em Lisboa (Tchen 2001), sempre foi desaprovado e denunciado publicamente pelos neorrealistas. Este litígio talvez possa explicar uma certa partidarização artística por parte das revistas estudantis. No entanto, importa referir que, do mesmo modo que alguns poemas neorrealistas foram publicados na revista Quadrante, também nas páginas da Via Latina surgem dois poemas surrealistas, um de Mário Cesariny, no número 101, e outro de Alexandre O'Neill, no número 93, exclusivamente. De notar que, apesar de tanto Cesariny como O'Neill terem tido influências neorrealistas, os poemas mencionados enquadram-se no surrealismo.

Excetuando a menção da importância do movimento num artigo dedicado à evolução da história da arte, o movimento surrealista não teve praticamente nenhuma exposição na Via Latina. O jornal dos estudantes católicos de Lisboa, Encontro, que também se destacou na época pelo papel de relevo dedicado à cultura, raramente menciona o movimento neorrealista, e, quando o aborda, descreve-o como um método artístico incipiente, imputando aos escritores neorrealistas a culpa de "acentuar as fraquezas da sociedade", por estes criticarem "impiedosamente aqueles que mais diretamente por ela podem responder". Acusa-os ainda de "se desviarem da literatura" para "o plano exclusivo da luta de classes" ao insistirem em "figuras unilaterais, boas ou más, consoante a classe a que pertencem" ("A propósito do": 7). O próprio Aquilino Ribeiro, não sendo neorrealista mas detendo contornos estéticos facilmente enquadráveis no realismo/naturalismo, foi veementemente criticado nas páginas de Encontro. 
Cadernos de Literatura Comparada

Da Criação Literária Universitária como Contra-hegemonia ao Estado Novo: O Caso da Via Latina (1958-1962)

Ribeiro foi considerado um "renovador da língua até ao exagero", obcecado com a "sexualidade e o anticlericalismo". "Uma crítica séria e posterior arrumará muitos dos últimos volumes saídos da pena do autor de O Malhadinhas como inferioridades infelizes." ("Aquilino": 5)

\section{O existencialismo na Via Latina}

A corrente literária existencialista, que marca a sua entrada no panorama literário português pelo intermédio da obra do autor Vergílio Ferreira no princípio da década de 1950 (Saraiva/ Lopes 2000: 1091; Sacramento 1968: 64), sustentou-se na escola do pensamento filosófico existencialista. $O$ existencialismo é uma corrente caracterizada pela crença de que as reflexões filosóficas tomam como ponto de partida a existência. Ou seja, inverte o clássico pensamento de Descartes, penso logo existo. Para o existencialismo o ponto de partida da reflexão é o indivíduo colocado num mundo a priori absurdo, confuso e sem sentido. O positivismo e o racionalismo não conseguem desvendar todos os fenómenos da realidade, a consciência humana e a existência são algo sem aparente explicação. Cabe ao homem, através da autorreflexão, tentar transcender a angústia e as dificuldades que se lhe apresentam (Emanuele 2001: 236-245). Os filósofos existencialistas foram assim categorizados dado o facto de a questão da existência ocupar um papel central na sua obra, apesar das inúmeras diferenças que apresentam. Estes autores renegam a capacidade que as ideias e filosofias académicas, bem como o conhecimento científico generalizado, têm para explicar todos os mistérios relativos à existência humana e ao absurdo da vida quotidiana, considerando-as demasiado afastadas das experiências reais e, por isso mesmo, utópicas. Para os existencialistas é na própria vivência que se pode encontrar a felicidade humana. De acordo com Alexandre Morujão:

O mundo deixa de ser uma teia de relações matemáticas ou matematizantes, ligando exteriormente fenómenos esquemáticos, apresentados a um sujeito esquemático que também é, por isso mesmo, utópico. Volta a existir mundo para o homem em que as palavras destino, liberdade, opção, risco e fé possuam um sentido; em que o outro, o próximo, se ergue prenhe de significação; em que fazer filosofia não se resume a sistematizar o saber positivo, nem em reflectir sobre as condições lógicas da sua possibilidade, voltando costas à vida, construindo um sistema em que tudo é explicado menos a existência. E nestes anos da tragédia que o mundo sentiu tão abandonado, em radical soledade, tornou-se mais patente ainda esse desejo do concreto, do real em tudo a sua plenitude de que homem carece para viver [sic]. (Morujão 1954: 22-23)

Dada a diversidade do pensamento existencialista, os únicos autores referidos serão Jean-Paul Sartre e Albert Camus, pelo facto de serem os únicos que gozam de considerável espaço nas páginas das publicações universitárias portuguesas do período 1958-1962.

Contrariando a revista Vértice, que renegou o existencialismo ao rotulá-lo como uma teoria individualista e afastada da realidade (Ramond 2008: 375-376), o mesmo foi recebido com entusiasmo pela Via Latina. Apesar de algo escassos, os artigos relativos ao existencialismo são reveladores de exultação para com o movimento, em particular para Albert Camus. Em 1956, 
no número 72, a revista aborda pela primeira vez o existencialismo, num artigo sobre Jean-Paul Sartre onde a sua teoria é sinteticamente exposta. No número seguinte surge um texto dedicado a Camus que apresenta o romance existencialista como o verdadeiro romance moderno: "A literatura moderna é, portanto, uma literatura problemática, como problemática é a existência actual. A estabilidade dos séculos anteriores tornava a criação literária uma tarefa de certo modo aprazível". É verdade que assumir a criação literária prévia como "estável" pode ser encarado como algo simplista. Todavia, importa contextualizar esta afirmação no quadro cultural da época. Para o estudante coimbrão, que provavelmente só teria contacto com a literatura portuguesa clássica e com o neorrealismo, o existencialismo configurou-se enquanto algo inovador e drasticamente diferente das restantes estéticas literárias.

Este ensaio procura ultrapassar o aparente negativismo da obra de Camus: "Contudo, descobrir nela apenas pessimismo seria negar-se a compreender a missão de uma literatura que responde à realidade da época". A Peste (1961), a obra de Camus que este texto analisa, relata a história de uma cidade argelina sitiada pela peste bubónica. No decorrer do romance as vítimas da peste vão morrendo arbitrariamente. Um padre morre quando perde a fé. A personagem principal, o médico Bernard Rieux, que desde o princípio do romance cuida de doentes, chega incólume até ao final. Quando a peste finalmente começa a desaparecer da cidade, o amigo de Rieux, Rambert, morre subitamente (Camus 2006). Tudo é absurdo e inexplicável. O ensaio dedicado a este livro de Camus concluiu com o derradeiro propósito do existencialismo:

Viver não basta, nem lutas bastam tão pouco, mas acima da vida e da luta deve realizar-se uma união que não pode definir-se, uma união que Camus ainda desconhece, mas aos poucos parece descobrir. Veja-se agora o que diz na Peste, uma das personagens Rambert: "Sei agora que o homem é capaz de grandes acções mas se não é capaz de um grande sentimento não me interessa." (Rasteiro, "Albert Camus":13)

Após a morte de Camus em Janeiro de 1960, a Via Latina publica "Albert Camus ou o Absurdo e a Saga", um ensaio de Carlos Pereira de Carvalho. O autor refere que Camus tinha apenas uma missão: viver. "Viver e sentir humanamente com os homens, sinceramente. Humanamente sofrendo e vivendo com os homens. Amando com os homens. Odiando com os homens." Num mundo novo, o mundo contemporâneo do pós-Segunda Guerra Mundial onde mais nada faz sentido após a barbárie: "A sociedade absurda da negação do homem. O vegetar constante. $\mathrm{O}$ amarfanhadinho quotidiano. O nada. E uma sociedade de anónimos escravizados". A tecnologia e a ciência falharam, quando prometeram à humanidade a optimização do seu modo de vida: "Um século de limitações ao homem. De entraves. Opressão. Negações. Aniquilações. Absurdo. Um mundo absurdo". O ensaio referencia passagens de O Mito de Sisifo (1941) e A Peste (1947) para melhor ilustrar o pensamento existencialista de Camus. "Todos serão aniquilados pelo hálito maldito da doença. Embora se lute. Embora haja um trabalho insano para suster a epidemia. De nada vale. O homem é vencido e aniquilado" (Carvalho, "Absurdo": 8). Será apenas através da procura do sentido da sua existência, da autorreflexão, do diálogo, de um 
processo de libertação que até o próprio Camus desconhece, que o homem conseguirá alcançar a felicidade:

Absurdo total. Nem esperança. Nem amor. Nem Deus. Tudo negado. Tudo negado por um processo humano, histórico. Em que Camus se filia. Mas há que vencer o absurdo. Há que libertar o homem. Há que dar-lhe felicidade. Ele que se encerre em si. Ele, que é a única realidade, que se feche. Que se pense. E como a Fénix ele tirará de si o que lhe falta. É de si que virá a felicidade. Ele próprio encontrará a solução. Basta-lhe o impossível. (Carvalho, "Absurdo": 8-11)

Também em Encontro, no mesmo mês em que Albert Camus morre, se pode encontrar um texto sobre a obra do autor argelino que se assemelha ao ensaio de Carlos Pereira de Carvalho. A Peste é mais uma vez eleita como o ponto de partida para a análise das contradições aparentemente insuperáveis da existência: "No mundo há crianças que sofrem, e a revolta em Rieux é um imperativo. A sua luta é um perpétuo anátema lançado a um universo sem sentido. Assim de uma atitude negativa, desentranha-se um magnífico ardor combativo. Há limites para a injustiça" ("Posição": 2). A Peste parece, de facto, ter sido uma obra bastante acarinhada pelos estudantes da época. Em "Do Zero Até Zero", o único conto existencialista assinado por um estudante publicado na Via Latina, sobressai uma passagem que denota uma possível leitura presente da obra de Albert Camus. Este conto de Alfredo Rasteiro narra a história de um rapaz entediado com o seu círculo de amigos, com a sua família e com o percurso académico. Com a vida, de um modo geral: "Já não tinham interesse para si as obrigatórias aulas aborrecidas de mestres enfadonhos. Já não tinham interesse para si as conversas com conhecidos nem as piadas trocadas à mesa do café. Deixou de conviver com os amigos e cada vez mais procurou a solidão da noite". Durante uma das suas passeatas noturnas vê uma mendiga em andrajos e a tossir. Ajuda-a a sentar-se na borda do passeio. Ela diz que tem fome e ele dá-lhe laranjas. Vendo-a a tiritar com frio, oferece-lhe a sua capa do traje. Afasta-se dela e caminha para longe, para depois divagar em pensamentos lúgubres: "Absorto, ia pensando na sua rota capa dada a uma mendiga que tinha frio" (Rasteiro, "Zero": 11). Assolado por dúvidas, emoções irracionais e um estado de profunda desinquietação, o estudante universitário entra em estado de puro delírio:

Viu rapariguinhas de rostos angélicos a atirarem-se aos braços dos homens, temendo se acabe o mundo. Velhos e velhas tísicos e nus e crianças a pedir esmolas. Mulheres que acabam de parir fremem de gozo se o médico ou parteira lhes lava os genitais. Homens depravados que vieram de manicómios. Empreiteiros, encarregues de obras, suicidas, assassinos profissionais. O seguro paga. Vira cadáveres a boiar em tanques de formol e outros, empestado de glicerina, esquartejados cheios de larvas de varejeira a bulirem. A apodrecerem em mesas de mármore. Era este o mundo em que teria de viver. Sorriu. (Rasteiro, "Zero": 11) 
Este ostensivo cortejo de pormenores grotescos, através do qual o autor procura fazer sobressair o absurdo da existência, é reminiscente das passagens mais violentas de A Peste. As visões ocupam-lhe todo o pensamento e atenção. Distraído, o estudante deixa-se atropelar por um automóvel. "Deitado de costas no meio do asfalto continua a sorrir. Indiferente ao polícia que atrapalhado tira notas e faz perguntas, continua a sorrir" (Rasteiro, "Zero": 11).

O existencialismo de Sartre e Camus, que em parte surge como uma resposta aos horrores da Segunda Guerra Mundial, ao colonialismo, e à opressão política e social, foi ademais aproveitado por uma juventude estudantil em mutação que ambicionou romper com a normatividade imposta. Esta tendência verificou-se um pouco por toda a Europa. Em Portugal, o existencialismo marcou entrada na produção literária através da obra de Vergílio Ferreira, como já foi referido; todavia, as publicações estudantis da época não mencionam o nome do autor português, optando por abordar apenas os consagrados existencialistas francófonos, como Camus e Sartre.

O existencialismo procurou continuar a combater a mesma ordem social que o neorrealismo, deixando, porém, de lado as descrições objetivas da realidade material e optando, ao invés, por uma leitura introspetiva dos fenómenos físicos. Num artigo presente na revista Quadrante, intitulado "A Crise da Juventude", encontram-se plasmadas as dúvidas que assolam o jovem moderno. A crença positivista na ciência como facto inevitável do progresso contínuo foi estilhaçada após a violência das guerras mundiais: "A evolução do animal racional" modelado pela experiência conduziu-o à amargura. O jovem de hoje surge-nos amargurado". Um jovem que se encontra separado da velha sociedade. "Outros apelidam desprezivelmente de existencialistas, de modernistas, de inconscientes todos os que não seguem a cartilha velha, bafienta e cheia de bolor que orienta o seu conformismo" ("A crise": 6). Da mesma forma que a revista Quadrante considera as dúvidas existencialistas, a Via Latina assume semelhante preocupação, fazendo, no entanto, uma análise mais profunda, ao assumir a delinquência juvenil (perpetrada por jovens burgueses) como uma resposta irrefletida para com o modelo social vigente.

Sendo assim, parece-nos que a verificar-se em Portugal um tal surto de delinquência este seria [proveniente] dos bairros de Alfama ou da Mouraria, e não da jovem e ociosa burguesia. Essa juventude que temos falado, e que constitui um grave problema para os governos - reúne-se em bandos, no instintivo desejo de sentir o bafo acalentador da solidariedade; e, na ânsia de se vingar de uma sociedade que ela, embora inconsciente, sente no próprio sangue como sendo culpada do descalabro, verificando-se, dentro e fora de si, essa juventude dizíamos torna-se cruel: atestam-no uma série de assaltos, roubos e violações. ("Angústia": 7)

A angústia sentida pela juventude foi interpretada como uma reação legítima para com uma sociedade opressora. Contudo, este descontentamento deve ser subordinado a um criterioso sentido crítico e, igualmente, ao sentimento de responsabilidade, para que se evite cair na violência e no vandalismo: "Precisamente a responsabilidade, no nosso entender, constitui o traço que distingue a juventude que falamos em primeiro lugar desta última [sic]". A angústia 
implica uma tomada de consciência que permita a revisão dos valores sobre os quais se alicerça toda a estrutura social. "Esta angústia não é definitivamente mais uma certidão, a juntar à irreverência das maneiras de ser ou de vestuário." (Angústia": 7)

Já Encontro encara o descontentamento juvenil como uma ingerência da cultura estrangeira cosmopolita. O rock ' $n$ ' roll, as estrelas de cinema, bem como as "meninas de calças e despenteadas a ler Sartre e Dali [sic]", são os verdadeiros sintomas de uma sociedade em decadência ("Crise juvenil": 14).

As três publicações aludem às temáticas juvenis e às problemáticas existencialistas num momento charneira da sociedade portuguesa. Com o principio dos anos 60 e apesar do sufoco provocado pela ditadura do Estado Novo, o país testemunhou uma renovação de gostos e comportamentos culturais. No artigo "Portugal, sociedade dualista em evolução", publicado em 1964, Adérito Sedas Nunes afirma que a sociedade portuguesa de então se encontra muito mais intensamente posta em presença com o mundo que a rodeia ( $v d$. Nunes 1964).

\section{o Centro de Estudos Literários}

O Centro de Estudos Literários (CEL) começou por ser um esboço de um projeto de um clube literário. Em janeiro de 1960, sob a assinatura de José Carlos Vasconcelos, é publicado na Via Latina "Sobre a necessidade de um clube literário". Este artigo apela à criação de um organismo que procure valorizar a difusão e a criação literária. Tomando como ponto de partida a dinamização artística pela qual a AAC passava, José Carlos Vasconcelos interroga por que razão não fora criado um clube literário:

Só a literatura não tem qualquer entidade cujo fim, [sic] seja primordialmente o seu estudo e a sua divulgação; isto na principal Universidade dum País, que, precisamente (e julgo não ser gratuita a minha afirmação) tem nas letras - especialmente na poesia - o seu principal motivo de orgulho...

Porque não havemos nós de ter um clube literário? As suas actividades podiam ser variadas, entre elas - por serem maiores as possibilidades de realização - destacamos: conferências sobre escritores. Seguidas dum colóquio (o qual, sempre que possível, teria a presença do escritores causa), à semelhança do que já se vem fazendo, com bons resultados na Associação de jornalistas e Homens de Letras do Porto. Porque não formarmos pois, um clube literário? ("Sobre": 1-3)

No número seguinte Armando Luiz responde ao artigo de José Carlos Vasconcelos, afirmando que a criação de um clube literário seria uma inutilidade, tendo em conta a abundância de textos literários publicados na Via Latina e a possibilidade de uma eventual infiltração político-ideológica. Para Armando Luiz, "nenhum outro ramo das artes é tão esquivo a ideologias pré-formuladas e impostas, como a literatura". Por esta ser um "veículo de afirmação necessário ao equacionamento de qualquer trabalho da razão. Porque o espírito humano é único e não uno" ("Ainda": 7). No ano letivo seguinte (1960-1961), no qual a presidência da AAC é encabeçada por Carlos Candal, é publicada uma notícia que confirma a criação do CEL, assinada 
pelo estudante que propôs a sua criação e que foi nomeado diretor do organismo, José Carlos Vasconcelos. O diretor do CEL afirma que com a criação do Círculo a "Academia se encontra mais próxima do ideal pelo qual devemos lutar", e que "a cultura pressupõe esclarecimento. E quanto maiores estes forem, maior será indubitavelmente, aquela solidariedade que nos deve unir, a nós e aos alunos de outras universidades". O CEL propõe logo desde a sua origem divulgar a produção literária contemporânea, promover conferências sobre escritores e "iniciativas tendentes a desenvolver o gosto e as aptidões para a criação literária no seio da Academia, até à organização de cursos especiais sobre diversos temas e a criação de uma boa biblioteca para uso dos universitários" ("Meditação": 1-2). No mês seguinte o CEL publicita a "futura possibilidade de passar a organismo autónomo, dado a sua relevância", e a organização de duas sessões dedicadas a Fernando Pessoa e uma antologia de poesia estudantil ("Uma notícia", 9-11). Durante os anos letivos de 1960-1961 e 1961-1962, o CEL revelou-se bastante dinâmico ao promover com frequência a realização de vários debates e colóquios. Entre estes eventos destacam-se a realização de uma conferência sobre Eça de Queirós que contou com a presença de Manuel da Fonseca; uma iniciativa conjunta entre o CEL e o Centro de Estudos Cinematográficos da AAC sobre a relação entre a literatura e o cinema; um debate sobre a mulher no romance contemporâneo, onde se abordam os "mitos femininos criados pelas preocupações e sonhos masculinos"; a abertura de um curso sobre o romance português dividido nas seguintes lições: "Camilo e a tradição romântica do romance português", por Vitorino Nemésio, "Naturalismo, regionalismo e reação anti-naturalista", por Joel Serrão, e Neo-Realismo e realismo crítico", por Óscar Lopes.

Destaca-se também uma conferência dada por Óscar Lopes através da qual se traçou o percurso do movimento neorrealista, desde a sua origem até ao presente. O colóquio abordou vários pontos:

1- realismo (segundo o qual a arte é a própria realidade, as próprias leis do real e de tudo o que melhor determina o homem) - realismo crítico (realismo de desconstrução, na medida em que critica aspectos da sociedade) - naturalismo (segundo Luckacs esta corrente "procura degradar uma sociedade degradada) 2 - Caracterização do legado do naturalismo português 3 - Aquilino Ribeiro - a sua evolução 4 - Psicologismo e neo-realismo - as suas complexas relações (o saldo positivo do psicologismo é essencialmente a dum correctivo ao naturalismo - veio portanto tratar dum campo que os naturalistas esqueceram. (Vasconcelos, "Conferência": 8)

De acordo com o presidente do CEL, o debate foi útil na compreensão de como surgiu e evoluiu o neorrealismo na literatura portuguesa (Vasconcelos, "Conferência": 8).

Além da criação de colóquios e conferências, o CEL levou a cabo um Concurso Literário da Queima das Fitas aberto a todos os estudantes do Portugal metropolitano e ultramarino. De ressalvar também a importância do mecenato da Fundação Calouste Gulbenkian. A Fundação, e o seu sector de leitura pública (presidido por Branquinho da Fonseca, um intelectual oposicionista), tiveram um papel importantíssimo na difusão literária nacional durante as décadas de 
1950 e 1960. Criaram uma biblioteca itinerante e conseguiram articular-se com outras entidades da sociedade civil, tais como alguns municípios e associações livres (Melo 2001: 117-118). AAAC foi uma associação que em larga medida beneficiou do apoio prestado pela Fundação Calouste Gulbenkian. O crescente descontentamento que os estudantes tinham para com a inexistência de uma biblioteca universitária (que só seria criada no final do ano letivo de 1961-1962), bem como para o acesso a novas leituras, levou o CEL a pedir apoio à Fundação. De ter em conta que para um estudante da época era bastante difícil obter novos livros. Nas opiniões de Rui Namorado e Eliana Gersão (estudante e membro da redação da Via Latina), a única maneira seria através das bibliotecas de família ou através de aquisição. E, tendo em conta o estatuto financeiro do estudante, este não conseguiria comprar mais do que dois livros por mês (Namorado 2015; Gersão 2015). O CEL, com o apoio da Fundação Calouste Gulbenkian, em 1961, começou assim a constituir a uma biblioteca. Recebeu uma remessa com livros de várias editoras, onde se salientam obras de Manuel da Fonseca, António Nobre, Eugénio de Andrade, José Rodrigues Miguéis, Anton Tchekov, Bernardo Santareno, Teixeira de Pascoaes, Florbela Espanca, Charles Baudelaire e Gustave Flaubert (Vasconcelos, "Para uma biblioteca": 3).

Num contexto de asfixia da liberdade e da autonomia estudantil e social, a criação e a produção literária universitária foram transformadas num espaço de contestação. Paralelamente, os estudantes levaram a cabo uma série de práticas, tais como eventos literários, concursos de contos ou a criação de um clube literário, que procuravam, mais do que politizar o meio académico, fomentar a divulgação e a criação literária no contexto universitário.

Ao mesmo tempo, a criação de um organismo autónomo como o CEL pode ser interpretada como uma tentativa de criar um lugar de difusão, debate e produção literária salvaguardado das ingerências governamentais.

\section{Nota final}

A relação do estudante de Coimbra com a literatura assentou sobre três eixos: 1) a vontade de desenvolver a criação e a divulgação literária no meio académico, um ensejo que se consubstanciou na formação do Centro de Estudos Literários; 2) utilizar a criação literária enquanto elemento de qualificação intelectual e política e complemento da formação universitária; 3) instrumentalizar a criação literária como ferramenta de combate à ditadura. Durante o período estudado, praticamente todos os contos e ensaios publicados na Via Latina apresentam um carácter dissidente face ao regime e ao seu discurso.

Paralelamente, as preferências literárias da Via Latina distinguem-se das restantes publicações universitárias da época devido à sua adesão ao neorrealismo e a uma postura claramente refratária. Também a formação do CEL sintomatizou uma forma mais sofisticada de conduzir um processo de sensibilização literária no seio da Academia. A criação de uma biblioteca gerida pelos estudantes e a organização de eventos participados por intelectuais oposicionistas são reveladores desta simbiose entre criação artística e dinamização política. 


\section{NOTAS}

* Pedro Réquio é licenciado em História na Faculdade de Letras da Universidade de Coimbra. Mestre em História Contemporânea pela mesma instituição. A sua dissertação de Mestrado intitulou-se Mudança Cultural e Política da Academia de Coimbra: 0 Caso da Via Latina (1958-1962). É investigador júnior no projeto 25AprilPTLab e encontra-se a realizar o doutoramento Discursos: Cultura, História e Sociedade. As suas áreas de domínio centram-se na História política e cultural do século XX e também nas ligações entre a arte, as ideologias e o exercício do poder.

${ }^{1}$ Única Revista dedicada a publicação de ensaios e contos de intelectuais de opositores ao Estado Novo.

${ }^{2}$ Revista oficial do movimento neorrealista.

${ }^{3}$ Dois estudantes universitários que fizeram parte da revista Via Latina.

${ }^{4}$ Ver Gaibéus e Esteiros.

\section{Bibliografia}

- (1959), "Crise juvenil", Encontro. 4, 6-7.

- (1959), "A crise da juventude", Quadrante. 2, 7-8.

- (1960), "A posição existencialista", Encontro. 14, 2.

- (1960), "Bi-dimensão psico-burguesa", Via Latina. 120, 5.

- (1960), "Manifesto juvenil", Via Latina. 120, 5.

- (1960), "Aquilino Ribeiro", Encontro. 7, 2.

- (1962), "A propósito do neo-realismo", Encontro. 24, 3.

- (1959), "Angústia da juventude", Via Latina. 89, 7.

Alegre, M. (1961), "Como se houvesse festa", Via Latina. 123, 7.

Camus, A. (2006), A Peste. Carnaxide, Coleção Nobel.

Carvalho, C. P. (1960), "Albert Camus ou o absurdo e a saga", Via Latina. 110, 8-11.

Emanuelle, E. (2004), Penso Logo Existo - Uma breve história da Filosofia. Lisboa, Círculo de Leitores.

Freire, H. L. (1959), “Do Menosprezo pelos poetas", Via Latina. 89, 5.

Garrido, A. (1996), Movimento estudantil e crise do Estado Novo. Coimbra, Livraria Minerva.

Gersão, T. (1959), "Uma história para pobres", Via Latina. 96, 6-7.

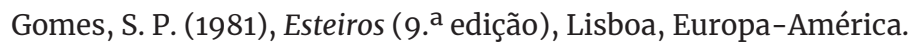

Gramsci, Antonio (1974), Obras escolhidas, vol. 1, Lisboa, Editorial Estampa.

Luiz, A. (1960), "Ainda o problema da criação do clube literário", Via Latina. 106, 7. 
Mansilha, M. (1959), "Vindimas", Via Latina. 85, 8-13.

Melo, D. (2001), Salazarismo e cultura popular. Lisboa, Imprensa das Ciências Sociais.

Morujão, A. F. (1954), Em torno do existencialismo. Coimbra, Estudos.

Mota, A. (1960), "Recordações de um escravo romano", Via Latina. 107, 4-5.

Neiva, T. (1961), "A Montanha", Via Latina. 122, 12.

Nunes, Adérito Sedas (1964), "Portugal, sociedade dualista em evolução" in Análise Social, vol. 2, n. ${ }^{0}$ 7/8. Instituto de Ciências Sociais da Universidade de Lisboa. pp. 407-462.

Ramond, V. (2008), A Revista Vértice e o neorrealismo português. Coimbra, Angelus Novus.

Rasteiro, A. (1959), "Albert Camus", Via Latina. 73, 7-8.

Rasteiro, A. (1959), "Do Zero até ao Zero", Via Latina. 87, 11.

Redol, A. (1989), Gaibéus (17. a edição), Lisboa, Caminho.

Rosas, Fernando (1994), História de Portugal, volume 7: O Estado-Novo 1933-1974, Coordenação de José Mattoso, Lisboa, Círculo de Leitores.

Sacramento, Mário (1968), Há uma estética neo-realista?, Lisboa, Publicações D. Quixote.

Saraiva, A. J./ Lopes, Ó. (2005), História da literatura portuguesa (17. a edição), Porto, Porto Editora.

Oliveira, C. (1961)., "7 poemas”, Via Latina. 123, 11.

-- (1962), “2 poemas", Via Latina. 136, 6.

Tchen, A. G. (2001), A Aventura Surrealista. Lisboa, Edições Colibri.

Torgal, L. R. (1999), "'Literatura oficial' no Estado Novo: Os Prémios Literários do SPN/SNI", Separata da Revista de História das Ideias, Volume XX. Coimbra, Faculdade de Letras da Universidade de Coimbra.

Vasconcelos, J. C. (1960), "Sobre a necessidade de um clube literário", Via Latina. 105, 1-3.

- (1960), "Meditação e notícia sobre a criação do Círculo de Estudos Literários", Via Latina. $121,3-4$.

- (1960), "Uma notícia mais sobre a formação do Círculo de Estudos Literários", Via Latina. 123, 9-11.

- - (1961), "Para uma biblioteca da Associação Académica, a Comissão do Círculo literário para a biblioteca", Via Latina. 128, 3.

-- (1962), "Conferência de Óscar Lopes", Via Latina. 141, 8.

\section{Entrevistas}

Eliana Gersão (08-10-2015).

Rui Namorado (15-10-2015).

António Avelãs Nunes (20-10-2015). 